\title{
The Effect of Trade Liberalization On Economic Growth: Selected MENA Countries
}

\author{
Naeimeh Hozouri ${ }^{1}$ \\ ${ }^{1}$ Department of Economics, University of Urmia, Urmia, Iran \\ Correspondenc: Naeimeh Hozouri, Band Rd, Jame Jam Blvd, Near Anna Hotel, No 82, Urmia, Iran. Tel: \\ 98-093-5474-5141. E-mail: n.hozouri@yahoo.com
}

Received: October 7, 2016

Accepted: November 4, 2016

Online Published: December 14, 2016

doi:10.5539/ijef.v9n1p88

URL: http://dx.doi.org/10.5539/ijef.v9n1p88

\begin{abstract}
This paper investigates the combined effects of international trade on economic development deals and tariff rates. A sample of 12 countries (selected countries MENA) during the period of 2000-2013, and the dynamic panel data model have been used for this purpose. Our results show that the sensitivity of economic growth have significant and inverse relationship with tariff changes, though its relationship with trade volume is positive.
\end{abstract}

Keywords: economic growth, liberalization, MENA countries

\section{Introduction}

One of the most important issues in international economics literature is the evaluation of relationship between economic growth and international trade and the literature on the relationship between trade liberalization and economic growth at the macro and micro level has secured itself a special place in studies. Do foreign trade can be the driving force in the development of a country? Or on the contrary, the theory of comparative advantage is incompatible with the needs of rapid growth and development. In general, the main issue is whether countries will be able to benefit more in globalization process of the economy (which will also be inevitable). To answer to this question, it should also be noted that the countries success depends on the economic structure, rules and regulations that govern the country and the ability of country in the international market arena. Without doubt, any new trade policy can have advantages and disadvantages, but we have to see whether or not its advantages are more or its disadvantages? With the development of trade relations between countries, different economic theories have been proposed, trying to design mechanisms to maximize the welfare and interests of communities and nations participating in the global trading system.(Abrishami et al., 2010)

In this paper we try to examine the effect of trade liberalization on economic growth, providing appropriate econometric models with regard to the special structure in selected Middle East and North Africa (MENA) countries. To do so following hypothesis is tested: trade liberalization has a positive effect on economic growth in MENA countries. The results of the paper can be used to correct policies for economic growth.

The rest of the paper is organized as follows: Section 2 described the nature and theoretical bases of trade liberalization. In section 3, we review the previous studies and described methodology and data analysis in section 4 . Section 5 results. Section 6 concludes the paper.

\section{The Nature and Theoretical Bases of Trade Liberalization}

Trade liberalization at the international level is a phenomenon that can provide economic development and growth through the international division of labor and specialization among countries. To this date, several theories have been proposed in the field of international trade liberalization which all aims to findthe establishing basis, direction and quality of benefiting countries from international trade. Basic theory ofinternational trade is originated from the collision of economic theoriesdiscussed in previous centuries. The most important of these theories that can be named are Merchant lists (dealers or gold-savers), views of Adam Smith and David Ricardo (scholars of the classical school of economics) (Mohtasham, 2006).

Merchant's theory that was propagated from the thirteenth century until the mid-eighteenth century in countries such as Great Britain, Spain, France and the Netherlands after propagation of business by European traders, insisted on first to win gold and silver in every way possible, second to increase the wealth and power of the central state, and third; direct intervention of the state in economic affairs and its control (Pazhouyan \& Jahromi, 
2004). Merchants believed that the most important way for a country to be rich and powerful is for its exports to be more than it imports, and the difference to be paid in a precious metal such as gold. In this regard, they identified stronger countries on the basis of having more gold. Hence, traders supported the idea that the government should encourage exports and restrict imports (Bidabad \& Tabari, 2005). Today, the Merchant's theory is rejected, because the realities of international trade show that no country can just be exporting and limit importing to a very big extent. Today, even the largest economic powers in the world are not able to restrict imports. According to Christina Sevilla, assistant for the trade representative for intergovernmental affairs and public relations of foreign affairs department of USA, even the United States which in the twentieth century is one of the biggest economic powers in the world is not able to limit imports, so America is considered world's largest economy and the biggest exporter and importer (Abrishami et al., 2010). So, Merchant's theory cannot be the basis for international trade in today's world.

Adam Smith questioned the assumptions of trader's theory in the book Wealth of Nations in 1776. He believed that free trade between countries caused the division of labor; factors of production will be concentrated in producing goods which are produced more cheaply than other countries good. It is in this case that both countries benefit from trade. He argued that through free trade, any deductions can specialize in producing goods in which they have an absolute advantage (Bidabad \& Tabari, 2005). This theory also cannot work due to the factsof global economy, because it can cover economiesthat have an absolute advantage; yet only a handful of countries have an absolute advantage in the contemporary world in particular fields. Ricardo's theory of comparative advantage was introduced later. Ricardo believed that even if a country has an absolute advantage in producing two goods than any other country, bilateral trade with advantage could still be done (Rahimi, 1995). Thus, the country that has higher absolute advantage in the production of a commodity (comparative advantage), have to produce and export that commodity, while other countries which have higherabsolute advantage in producing the second commodity, should be engaged in the production and exportation of second commodities (Mohtasham, 2006). Effect of trade and market development on growth isan issue that was raised by Adam Smith more than two centuries ago and today is still discussed. Some policymakers and economists believe that trade liberalization (lower trade restrictions) leads to better macroeconomic performance and faster economic growth. Empirical studies suggest the view that trade liberalization has a positive impact on economic growth, thus the positive link between free trade and economic growth, has made a good motivation for an unprecedented aspect of trade reformation in the last twenty years, so that 100 countries have committed to some sort of trade liberalization (Greenaway et al., 2002). New growth theory suggests that trade allows producers' access to larger markets and causes the developing countries to have access to capital goods and an intermediate for the process (flow) of development, which are critical. Finally, if the growth engine can be the new products supplier, then trade will play an important role in economic growth by providing access to new institutions and entities (Gorji \& Alipuryan, 2006). On the other hand, some economists are skeptical of the positive impact of liberal trade policy oneconomic growth andbelieve that experimental studies are faced with methodological dilemmas, so that the results of these studies has not stability compared to clarifying the model, sampling and time period;and so the results are at best weak and at worst misleading. If the ratio of foreign trade to national production is once a raw scale which shows country's dependence on other countries markets and supplies, then if country'sexports and imports, include only defined numbers of goods and special parts of economy, the dependence will become stronger. In any case, foreign trade ratio can be used as an approximate measure for country's dependence tothe flow of materials from or to the country from other countries of the world.Thus, reliance and dependence of the smaller countries of the world to foreign trade must directly be linked to the level of economic development of the country and inevitably to the capital income of the country. This could be the reason for the claim that larger countries could rely on foreign trade for growth and that is why the share of foreign trade in their national production is larger. In contrast, it can be argued that larger countries with less reliance on foreign trade can have economic growth, although reliance on inflow or outflow of resources and materials to a country from the rest of the world is not necessarily a prerequisite for development, although it may happen. Surely if the economies of smaller countries want to have an advantages in production and savings originated from scale and achieve higher economic growth, not only dothey have to have a high economic efficiency of capital, rather they have to achieve higher reliance and dependence to foreign trade than larger countries,because the domestic market and domestic resources are not so vast and abundant to provide the possibility of achieving comparative advantage and savings of scale in the production for them (Kuznets, 1992).

\section{Review of Previous Studies}

Rahimi Boroujerdi (1991), have done a study on the impact of trade variables on economic growth in oil-exporting developing countries. The model used in this study, is a Conventional Specification model adjusted 
on the base of a functional relationship between the economic growth of mentioned countries and the five independent variables of export price growth, export trade growth, international interest rates, the growth rate of labor force and capital growth rates. The results show that export prices and export revenues which oil makes up the bulk of it, has a positive effect on growth in the long term.

Renault and Levine (1992) and Harrison (1996) investigated the partial correlations between the nominal freedom and economic growth in transition countries. In these studies it was found that there is a positive correlation between these two variables. But Renault and Levine stated that if we consider other variables that explain economic growth, this correlation will be of no significance.

Barro and Sala-I-Martin (1995) and Sala-I-Martin (1997) have done a study to define the factors affecting economic growth- which is considered the average growth rate of GDP- and generally seven variables, including the initial level of capital income and life expectancy in the base year were definedthat appears in the right side of each regression, growth appeared in previous studies on different countries and are common between all models of development and were significant. In these studies to avoid the problem of endogeneity variables of the base year are used. Sala-I-Martin has considered control variables of life expectancy and primary school attendance as a measure of human capital and the working population as a control variable for the size of the domestic market. He concludes that the life expectancy variable and primary school attendance rate is positive and significant and has influence on growing, but the population variable, is not significant and has no effect on growth.

Nasirzadeh (1996) has investigated the relationship between exports and economic growth in developing countries in the period of (1985-1993).This study examined how the exports affects economic growth and the effect of exports on economic growth is estimated with econometric models, and export development strategy has been targeted and represents clear advantages of this strategy in the economic development of countries. Estimates applied in this study for the years of (1985-1993) shows that one percent increase in export growth, will increase the growth rate of GDP per capita approximately 39 percent and transfer of resources from non-exportable and inefficient sectors to the more efficient export sector will accelerate economic growth.

Heydariyan (1996), in his study investigated the causal relationships between economic growth, export growth and the growth of production factors (labor force and capital) in form of a Vector Auto-Regression (VAR) model for the economy of Iran in the period of-1959-92. To determine the causal relationship between the variables in this model, first tests have been done to prove the adequacy and appropriateness of the model which demonstrates the adequacy of the model. Then to test the assumptions, he has used Wald test which indicates that export growth is the cause of economic growth; which means the results support the theory of growth relying on export and there is causal feedback between capital growth and economic growth and also between the growth of production factors (labor force and capital growth).

Hafezi (1998), in a research with the title of foreign trade affecting the economic growth, using techniques of integration, has discussed the impact of foreign trade on economic growth. The results indicate that the growth of the capital stock has a significant effect on economic growth, but there is not significant correlation between job growth rate and economic growth. They concluded that the growth of exports and imports has a significant positive effect on economic growth and the impact of exports on economic growth is higher than the impact of imports.

Gholami (2000) has investigated the relationship between economic growth andexports growth in Iran. In this study, hypothesis based on export for Iran economy during the period of (1959-95) was studied using exogenous test and causation. The results indicate that export variable can be used as an exogenous variable in the production growth function. Results of Granger causation about total export and economic growth indicate a two-sided causal relationship between these two variables and generally, support the results of export-based growth hypothesis in Iran and recommend following the exogenous policies for economic growth.

Alesina, spolaore and Wacziarg (2000) studied the interaction between free trade and the size of the countriesannounced as the size of the domestic market- and the effect of these factors on economic growth in all the countries (The sample size was according to given access to the required data for the period 2000-1960 for studied variables). In this study, the nominal freedom for the study period have been considered as a measure of trade liberalization and population size as a measure of the size of the domestic market and the logarithm of capital income in the base year as exogenous and influential variables on growth. The model used in this study, is the correlation test between free trade, economic growth and the size of the country. The results illustrate that free trade has a positive relationship with growth and taking in to account the inter action between free trade and market size, the result is that countries that have smaller size of the domestic market, benefit most from trading. 
Dutta and Ahmad (2001), using endogenous growth model frame, analyze the relationship between trade policies and industrial growth in Pakistan during 1995-1973. The results of the co-integration approach, shows a unique long-term relationship between group growth function and the main factors determining it such as: capital stock, labor force, real exports, the average import tariff rate and human capital. In short term, the behavior of added industrial value for growth function significantly changes into the long-term with a mild speed.

Frankel and Rose (2002) used qualitative variables and control variables to analyze the effect of trade and the market size on economic growth of 200 countries during the period of 1995-1970. In this study, only nominal freedom is used as a measure of trade freedom and research model is a two-step approach that first step, a gravity equation to analysis the effects of currency on countries trading, is estimated using OLS method and later stage, a growth regression set for studied countries and it also is estimated using OLS. The results show that each one percent increase in trade (relative to GDP), increases capital income to 0.33 percent and the size of the domestic market has an impact on growth.

Also, Greenaway, Morgan and Wright (2002) have used a dynamic panel model in their article to analyze the effects of trade liberalization on economic growth in a sample of 73 countries for the period of 1965-1985 which; in addition to considering the many factors that affect the growth as a control variable, have used series of other characteristics as openness and trade liberalization variable.

Masoudzadegan (2002), in his study examined the effect of foreign trade on economic growth of Iran. In this regard, in this study we tried to investigate the theory of trade as an engine for Iran's economic growth in the period 1367 to 1373 using data table of input-output. Assessing the matrix of input-output in the years 1367 and 1373 shows that in these years, the greatest impact ofexport in each sector is on the growth of the same sector and the most indirect effect on the growth of other sectors belongs to industrial sector while the lowest is for oil sector. Also, evaluation of country's economy in the period of 1367 to 1375 shows that the main factor of economic growth have been the expansion of domestic market that had a huge impact on economic growth, expect for the oil sector which export growth is the major factor for the growth in this sector.

Heydari (2002) has studied short-term and long-term causal relationships between foreign trade and economic growth in Iran using a vector self-describing pattern during the period of (1959-2000). The results of long term causality show that in long run, causal relationship between export growth, import growth and GDP growth is bilateral.

Abrishami (2009) has investigated the relationship between foreign trade and economic growth in developing countries which its results indicate positive and poor trade growth rate on economic growth. In addition, trade barriers such as tariff rates can only cause small reduction in economic growth rate. Abrishami (2010) has studied the effect of free trade policies on economic growth of Islamic countries; the results indicate positive and poor effects of free trade policies on economic growth of the study area.

Gholipour et al. (2011) evaluated the impact of agricultural trade liberalization on export and import share of agricultural and service sectors of Iran. Results indicate that increased liberalization of agricultural trade has increased the share of exports and imports of agricultural and service sectors in the long term and short term. From another aspect, the share of agricultural and service sectors export in the short term under the impact of these policies has reduced. Falvey et al. (2012) addressed the effects of trade liberalization, economic growth and recession in an article. The emphasis in this paper is whether the crisis is a good time for trade reform? Is the economic crisis affecting the country at the time of trade liberalization on next growth performance of country? Threshold regression techniques are applied to identify five criteria indices to identify the values of crisis and estimate economic growth in critical and non-critical regimes. Our results indicate that although trade liberalization in both critical and non-critical periods increases the growth afterward, but internal crisis has a smaller acceleration and in external crisis, the acceleration is higher than the non-critical regime.

Dini et al. (2012) in an article entitled trade liberalization, financial development and economic growth in the long-term in Iran, have experimentally investigated the combined effects of trade liberalization and financial development in Iran on economic growth using endogenous growth models during the time period of 1965-2007. This theory shows the importance of economic growth policies that will lead to an increase in the return rate. It specifically states that human and physical capital, trade liberalization and financial development may have important roles to play in measuring economic growth. Empirical results of Johnson co-cumulating method indicate positive relationship between trade liberalizationand economic growth and negative relationship between financial development and their joint effects on Iran's economic growth. Summary review of the openness and trade liberalization and economic growth literature emphasizes on an important point that despite the extensive literature in this regard, yet no clear and definitive answer on this issue exist. Hence, it appears 
necessary to evaluate the effects of trade liberalization on economic growth in the selected countries of MENA region because the purpose of this research is to achieve high economic growth in the mentioned countries.

\section{Methodology}

\subsection{Model Introduction and Estimation}

The dynamic panel data methods are used in this paper. This method has been widely applied for analyzing the various impacts of globalization and external liberalization of economies, especially the effects of trade liberalization on economic growth. With regard to the previous part, a model similar to Greenaway, Morgan an Wright has been used in this paper expect for 17 countries and for an interval of 2000-2013 and dynamic panel inter-country regression approach Generalized Least Squares(GLS) which we will review its experimental results while introducing the model in this section.

\subsection{Data Analysis}

17 countries are used in this paper that primarily have certain homogeneity, because all of them are selected MENA countries and secondly have a long history of liberation and moving toward trade liberalization and removing tariff and non-tariff barriers considering the economic conditions in these countries that has been amore seriousagenda. Countries in this paper are the following: Iran, Algeria, Bahrain, Djibouti, Egypt, Jordan, Kuwait, Lebanon, Libya, Morocco, Oman, Qatar, Saudi Arabia, Syria, Tunisia, United Arab Emirates and Yemen.

\subsection{Variable Definition}

Generalized Method of Moments, an estimation tool for dynamic panel method are used to get to the relationship between economic growth and free trade policies developed by Arellano-Bond (1991), Arellano-Bover (1995), Newey and Rosen (1988), Holtz- Eakin ; and growth pattern is as follows:

$$
\Delta \text { Lny }_{i}, t=\alpha \Delta L n y_{i, t-1}+\beta x_{i, t}+\Delta \varepsilon_{i, t}
$$

$\mathrm{y}_{\mathrm{i}, \mathrm{t}}$ represents real GDP per capita, $\mathrm{y}_{\mathrm{i}, \mathrm{t}-\mathrm{l}}$ represents the real GDP per capita with the gap, $\mathrm{x}_{\mathrm{i}, \mathrm{t}}$ represents the matrix of explanatory variables and $\varepsilon_{i, t}$ represents the error. We use Arellano - Bond subtraction method to estimate and remove the fixed effects and use toolsmatrix to resolve correlation with continuous variable and other explanatory variables. In this Arellano - Bond method a two-step GLS estimators is offered.

In empirical studies, different variables are used for $\mathrm{X}$ vector, some of which are as follows:

Physical investment, human capital, trade openness, population, government expenditures, geographic variables, direct foreign investment, exchange rate premium, natural resourcesabundance, institutions and macroeconomic policy quality and ... considering the study case which are MENA countries and available information from following model are used to investigate the effects of trade liberalization on economic growth:

$$
\Delta \ln Y_{i,}{ }_{t}=\alpha \Delta \ln Y_{i, t-1}+\beta_{1} \Delta \ln T R A D E_{i,}{ }_{t}+\beta_{2} \Delta \ln T_{A R I F F_{i}, t}+\Delta \varepsilon_{i, t}
$$

$\Delta \ln Y_{i, t}:$ Growth rate of impure GDP per capita;

$\Delta \ln Y_{\mathrm{i}, \mathrm{t}-1}$ : Growth rate of GDP per capita with gap;

$\Delta \operatorname{lnTRADE} E_{i, t}$ : the growth rate of total trade (imports and exports of goods and services);

$\Delta \operatorname{lnTARIFF}_{\mathrm{i}, \mathrm{t}}$ : tariff growth rates on international trade.

\section{Results}

\subsection{Stationary Test}

Before the mode must there for ensure that no spurious regression is required before estimating models, unit root test for all variables used in the models, in general panel data method Levin, Lin and Chu to check whether or not there is a unit root. $\mathrm{H}_{0}$ The unit root tests are supposed to represent, or in other words Stationary data. $\mathrm{H}_{1}$ assumption implies that the data unit root test and have to say that Stationary. Stationary test results of individual variables are shown in Table 1. Stationary test results data by the method Levin, Lin and Chu in the table given below.

Table 1. LLC unit root test result

\begin{tabular}{lccc}
\hline & \multicolumn{2}{c}{} & \\
\cline { 2 - 3 } Variable name & Test level & prob & Test result \\
\hline Ln(GDP) & T-statistics & 0.0000 & $\mathrm{I}(0)$ \\
Ln(Tarrif) & -4.00456 & 0.0001 & $\mathrm{I}(0)$ \\
Ln(Trade) & -3.67705 & 0.0000 & $\mathrm{I}(0)$ \\
\hline
\end{tabular}


As is clear from the test results Stationary all variables are at Stationary.

\subsection{F-Limer Test}

Stationary after the test, as well as the fact that the variables in the model are static, be determined using the F-Limer the model should be used by pooling data and panel data methods.

F-Limer test the null hypothesis suggests the method is pooling data and assuming an explanation of the method of the panel data.

Table 2. Test cross-section fixed effects result

\begin{tabular}{lccc}
\hline Effects Test & Statistic & Prob & d.f. \\
\hline Cross-section F & 26.146375 & 0.0000 & $(16,219)$ \\
Cross-section Chi-square & 254.239851 & 0.0001 & 16 \\
\hline
\end{tabular}

As the estimation results of the test show that the null hypothesis has been rejected and there for should be the method of pooling data, panel data methods used.

\subsection{Hausman Test}

Based on the test results F-Limer, models should be based on panel data. Hence Hausman test should verify that estimate should be performed using fixed effect so random-effects on. Hausman test the null hypothesis suggests the existence of an express assumption of random effects and fixed effects.

Table 3: Random effects - Hausman test result

\begin{tabular}{lccc}
\hline Test Summary & Chi-Sq. Statistic & Prob & Chi-Sq. d.f \\
\hline Cross-section random & 8.389740 & 0.0151 & 2 \\
\hline
\end{tabular}

Based on estimated results of Hausman test, the null hypothesis is rejected and the fixed effects model estimation methods must be used.

Further more, regression of the independent variables on the remaining square regression can be seen that the changes in the independent variable, the remaining square regression a real so affected by the presence of variance difference, and should be Generalized Least Squares(GLS) method Was used. The model is extracted for 17 of MENA countries for the time period of 2000-2013 based on World Bank data (2015) because these data had better frequency and their estimationarepresented in the following table:

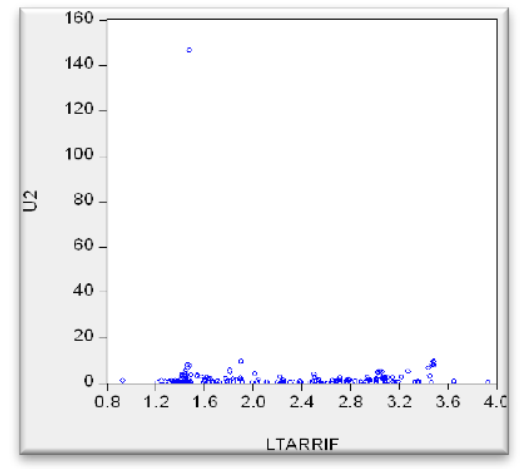

Form 1. Tarrif

The resulting model of GLS method below:

Table 4. Resulting model of GLS method

\begin{tabular}{lcccc}
\hline Variable name & Coefficient & Std. Error & t-Statistic & Prob \\
\hline LGDP(-1) & 0.903052 & 0.022940 & 39.36510 & 0.0000 \\
LTARRIF(-1) & -0.018662 & 0.008600 & -2.170050 & 0.0312 \\
LTRADE & 0.045063 & 0.021512 & 2.094719 & 0.0374 \\
C & 2.187812 & 0.576043 & 3.798003 & 0.0002 \\
\hline
\end{tabular}


The results show that the sensitivity of economic growth and as significant in verse relation to tariff changes and to changes in trade volume, the sensitivity is positive.

Watson statistic indicates the absence of auto correlation in the model of the camera has remained normal regression test showed disruption of normal sentences which are shown below.

\section{Conclusions and Recommendations}

Lord Bauer believes that initiation and innovation capability increases the efficiency of individuals and it is the cause for trading. Lewis believes that the decline of Britain's economic growth rate in 1870 was due to the fall of annual exports increase from 6 percent to 2 percent. One of the sources of total productivity gains may be due to trade liberalization. Trade liberalization makes domestic firms to achieve foreign factors of production to a wide level at a lower cost, resulting in transferring production function toward out. Trade liberalization has contributed to export growth. MENA region countries have applied the "Import Management" policy in this liberalization. Many studies report a positive relationship between various measures of trade liberalization and economic growth, however, there are disadvantages, and some studies suggest that the relationship between trade liberalization and economic growth is minimal. So far the researchers have not reached a definite and stable conclusion examining the effects of trade liberalization on economic growth.Not reaching to such a consensus has various reasons that majority of them are: first, the types of used index in studies are different that presumably can affect the results. Second, the periods used in these studies were different; and the third reason is that present defects in different econometric methods have caused problems during the investigation of such a relationship through scientific tests and also leads to ambiguouscontradictory and results in part of the data analysis. So it was not surprising to obtain different results.

Since one of the goals of world countries is liberation from the bonds of geographic bordersand moving toward an open and global economy, therefore, removing tariff and non-tariff barriers to free trade and the formation of appropriate and account import and export policies for a country will be necessary. In principle, trade liberalization in MENA countries, not only causes technology transfer through imports of advanced capital goods, transfer of commodities, services and financial resources of industrialized countries to their countries, but also the developmental or anti-developmental effects resulting from transfer of technology and usage patterns of these countries. The effect of such transfers on the development process can be positive or negative. Besides the export-dependency of MENA countries, these countries need the imports of raw materials, machinery, capital goods, intermediate goods and consumer goods to strengthen and expand industrial system and cover the growing consumption needs of their citizens. The balance of imports and exports of goods in studied countries to support the manufacturing sector requires the reduction of imports, increase of exports or domestic consumption that there is this problem in all three parts. Adopting supportive policies for competitive domestic industries and resorting to tariffs methods for these products are effective approaches that will have consequential impact on the growth and improvement of country's economy.

\section{References}

Abrishami, H. et al. (2009). The relationship between foreign trade and economic growth in developing countries. Journal of Knowledge and Development, (26).

Abrishami, H. et al. (2010). The effect of free trade on economic growth. Politics, Economic Research Journal, (91).

Alesina, A., Enrico, S., \& Romain, W. (2000). Economic Integration and Political Disintegration. American Economic Review, 90(5), 1276-96. https://doi.org/10.1257/aer.90.5.1276

Barro, R. J., \& Xavier, S. I. M. (1995). Economic Growth. MIT Press, Cambridge, MA, 1999. (First edition published by McGraw-Hill, New York, 1995).

Bidabad, B., \& Tabari, F. (2005). Iran and WTO accession. Retrieved from http://www.bidabad.com/doc/wto-iran-gtml

Dini, H. et al. (2012). Trade liberalization, financial development and economic growth in the long run. Iran, Jahad, National Economic University.

Dutta, D., \& Ahmad, N. (2001). Trade Liberalization and Industrial Growth in Pakistan: A Cointegration Analysis. Sydney: Sydney University, School of Economics and Political Science. Retrieved from http://www.econ.usyd.edu.au/staff/ddutta/

Falvey, R., Foster, N., \& Greenaway, D. (2012). Trade Liberalization, Economic crises, and growth. World Development, 40(11), 2177-2193. https://doi.org/10.1016/j.worlddev.2012.03.020 
Frankel, J., \& Andrew, R. (2002). An Estimate of the Effect of Common Currencies on Trade and Income. Quarterly Journal of Economics, 117(2), 437-466. https://doi.org/10.1162/003355302753650292

Gholami, M. (2000). Examined the relationship between economic growth and export growth: The case of Iran (1959-1995). Shiraz University, Graduate School.

Gholipour, S. et al. (2011). The impact of agricultural trade liberalization on exports and imports of agricultural and services sectors. Iranian Journal of Agricultural Economics and Development, (4).

Gorji, E., \& Alipuryan, M. (2006). Analyze the effects of trade liberalization on economic growth OPEC countries. Research - Business Letter, (40), 187-203.

Greenaway, D., Morgan, W., \& Wright, P. (2002). Trade Liberalization and Growth in Developing Countries. Journal of Development Economics, 67, 229-224. https://doi.org/10.1016/S0304-3878(01)00185-7

Hafezi, M. (1998). Effect of foreign trade and economic growth in the use of technology convergence. Beheshti University, Faculty of Economics and Political Science.

Harrison, A. (1996). Openness and Growth: A Time-Series, Cross-Country Analysis for Developing Countries. Journal of Development Economics, 48(2), 419-47. https://doi.org/10.1016/0304-3878(95)00042-9

Heidari, M. (2002). Examined the causal relationship between foreign trade and economic growth in Iran (1959-2000): A Vector Auto Regression Model. MS Thesis, Shiraz.

Heidariyan, A. H. (1996). To determine the causal relationship between exports and economic growth in the VAR model using seemingly unrelated regression procedure repeated (ISUR) in Iran. M. Sc. Thesis, University of Technology, School of Industrial and Systems.

Kuznets, S. (1993). Modern economic growth (1st ed.). Translated by M. Nagor. Tehran: Institute of expressive culture.

Levine, R., \& David, R. (1992). A Sensitivity Analysis of Cross-Country Growth Regressions. American Economic Review, 82(4), 942-963.

Masudzadegan, S. (2002). Effect of foreign trade and economic growth in Iran using Input - Output table from 1988 to 1994. The ma e-Ali Sina University, Faculty of Literature and Humanities.

Mohtasham, D. T. (2006). International Economic Law, International Trade, International Finance (9th ed.). Pashutan, Tehran.

Nasirzadeh, M. (1996). Examined the relationship between exports and economic growth in developing countries (1985-93). MS Thesis, University of Mazandaran.

Pazhuyan, J., Kashi, K. H., \& Jahromi, M. (2004). General economics, PNU (6th ed.).

Rahimi, B. A. (1991). The role of international trade on economic growth in oil-exporting countries. Economic Research Journal, (43).

Rahimi, B. A. (1995). International trade relations contemporary theory and politics. The center of Islamic Azad University Press.

Sala-I-Martin, X. (1997a). I Just Run Two Million Regressions. American Economic Review, 87(2), 178-183.

Sala-I-Martin, X. (1997b). I Just Run Four Million Regressions. NBER Working Paper No. 6252, Cambridge, MA.

\section{Copyrights}

Copyright for this article is retained by the author(s), with first publication rights granted to the journal.

This is an open-access article distributed under the terms and conditions of the Creative Commons Attribution license (http://creativecommons.org/licenses/by/4.0/). 